\title{
PREVALENCE OF RISK FACTORS FOR HEALTH AND EMOTIONAL WELL-BEING OF TEACHERS IN THE CONTEXT OF DISTANCE LEARNING
}

Milushkina OYu' ${ }^{1}$, Zhukov OF', 3, Lukanova OV ${ }^{4}$, Markelova SV1 $₫$, Skoblina NA ${ }^{1}$

${ }_{1}$ Pirogov Russian National Research Medical University, Moscow, Russia

2 Plekhanov Russian University of Economics, Moscow, Russia

${ }^{3}$ Institute of age physiology, Moscow, Russia

${ }^{4}$ Secondary school № 72 Ulyanovsk, Ulyanovsk, Russia

Distance learning (DL) changed the work-rest balance of teachers, increased risks of deterioration of their health and emotional burnout (EB). This study aimed to investigate the prevalence of risk factors affecting health and emotional state of teachers engaged in DL, as well as subjective assessment of the significance of these factors by teachers. We have surveyed teachers during traditional, in-person learning (TL) period $(n=224)$ and DL $(n=619)$, and took anthropometric measurements of 45 teachers during TL and 72 teachers when DL ended. EB was studied in 72 teachers with the help of V.V. Boyko questionnaire. Statistical processing was enabled by the Statistica 13 PL package, Student's t-test, $\chi^{2}$ test; to identify the relationship between indicators, we relied on regression analysis, effect occurrence probability calculation. Less than half of teachers are aware of the health risk factors (low level of physical activity - $36.1 \%$, poor nutrition $29.2 \%$, lack of knowledge on disease prevention - 6.9\%). After DL ended, only 30\% of teachers considered themselves healthy; $13.1 \%$ reported lack of EB symptoms. An increase in the average body mass index value was established. Teachers underestimating EB and health risk factors were 2.3 times more likely to grow obese $(\mathrm{OR}=0.40 ; 95 \% \mathrm{Cl}=0.22-0.70)$. The study highlights high hygienic value of physical activity as a controllable health risk factor. Raising teachers' awareness of health preservation practices will help prevent deterioration of their health, development of EB and increase the efficiency of their professional activity.

Keywords: teacher, distance learning, health risk factor, emotional state, emotional burnout

Author contribution: Milushkina OYu — study management; Zhukov OF, Markelova SV, Lukanova OV — material collection, statistical processing, article authoring; Skoblina NA — literature analysis.

Compliance with ethical standards: the study was approved by the Ethics Committee of Pirogov Russian National Research Medical University (Protocol № 159 of November 21, 2016). Each participant signed a voluntary informed consent form. Adult population participated voluntarily, through filling in questionnaires online.

$\bowtie$ Correspondence should be addressed: Svetlana Valerievna Markelova Ostrovityanova, 1, Moscow, 117997; markelova_sv@rsmu.ru

Received: 19.03.2021 Accepted: 14.04.2021 Published online: 29.04.2021

DOI: 10.24075/brsmu.2021.019

\section{РАСПРОСТРАНЕННОСТЬ ФАКТОРОВ РИСКА НАРУШЕНИЯ ЗДОРОВЬЯ И ЭМОЦИОНАЛЬНОГО БЛАГОПОЛУЧИЯ УЧИТЕЛЕЙ В УСЛОВИЯХ ДИСТАНЦИОННОГО ОБУЧЕНИЯ}

\author{
О. Ю. Милушкина ${ }^{1}$, О. Ф. Жуков ${ }^{2,3}$, О.В.Луканова ${ }^{4}$, С. В. Маркелова ${ }^{凶}$, Н. А. Скоблина \\ ${ }^{1}$ Российский национальный исследовательский медицинский университет имени Н. И. Пирогова, Москва, Россия \\ 2 Российский экономический университет имени Г. В. Плеханова, Москва, Россия \\ ${ }^{3}$ Институт возрастной физиологии Российской академии образования, Москва, Россия \\ ${ }^{4}$ Средняя школа № 72, Ульяновск, Россия
}

Дистанционное обучение (ДО) изменило режим труда и отдыха учителей, увеличило риски нарушения состояния их здоровья и наступления эмоционального выгорания (ЭВ). Целью исследования было изучить распространенность факторов риска, воздействующих на здоровье и эмоциональное состояние учителей в условиях проведения ДО, и субъективную оценку учителями значимости этих факторов. Проведено анкетирование учителей в период традиционного обучения (ТО) ( $n=224)$ и ДО ( $n=619)$, антропометрическое обследование 45 учителей в период ТО и 72 учителей по завершению ДО. Изучено ЭВ у 72 учителей с использованием опросника В. B. Бойко. Для статистической обработки использовали пакет Statistica 13 PL, $t$-критерий Стьюдента, критерий $\chi^{2}$; для выявления взаимосвязи показателей - регрессионный анализ, расчет шансов возникновения эффекта. Менее половины педагогов информированы о факторах риска нарушения здоровья (низкая двигательная активность - 36,1\%, нерациональное питание - 29,2\%, отсутствие знаний по профилактике заболеваний - 6,9\%). После завершения ДО только 30\% учителей считали себя здоровыми, 13,1\% отметили отсутствие симптомов ЭВ. Установлено увеличение среднего значения индекса массы тела. Шансы развития избытка массы тела и ожирения у учителей, недооценивающих факторы риска развития нарушений здоровья и ЭВ, в 2,3 раза выше (ОШ = 0,40; 95\% ДИ = 0,22-0,70). Показано высокое гигиеническое значение двигательной активности как управляемого фактора риска нарушения состояния здоровья. Повышение информированности учителей в вопросах здоровьесбережения позволит сохранить их здоровье, предупредить развитие ЭВ и повысить эффективность профессиональной деятельности.

Ключевые слова: учитель, дистанционное обучение, фактор риска здоровью, эмоциональное состояние, эмоциональное выгорание

Вклад авторов: О. Ю. Милушкина - научное руководство; О. Ф. Жуков, С. В. Маркелова, О. В. Луканова — сбор материала, статистическая обработка, написание статьи; Н. А. Скоблина - анализ литературы.

Соблюдение этических стандартов: исследование одобрено этическим комитетом РНИМУ им. Н. И. Пирогова (протокол № 159 от 21 ноября 2016 г.). Добровольное информированное согласие было получено для каждого участника. Опрос взрослого населения проведен на добровольной основе с использованием онлайн-сервиса.

Для корреспонденции: Светлана Валерьевна Маркелова ул. Островитянова, д. 1, г. Москва, 117997; markelova_sv@rsmu.ru

Статья получена: 19.03.2021 Статья принята к печати: 14.04.2021 Опубликована онлайн: 29.04.2021

DOI: $10.24075 /$ vrgmu.2021.019 
In 2020, with COVID-19 pandemic and quarantine measures in the background, over 1.5 billion children, adolescents and youth were switched to distance learning (DL). Distance learning implies interaction of teachers and students at a distance, with all the components of educational process (goals, content, methods, organizational patterns, teaching aids) factored in. Distance learning relies on the specific constituents of the internet technology [1, 2].

Schools were forced to switch to distance learning strategies, but their experience of application thereof was limited [3].

Studies by both Russian and foreign researchers and educators have shown that switch to the distance mode of learning entailed increased loads on all educational process participants (teachers, students, parents) [4-9], which caused disorders in general and distressed emotional well-being of teachers in particular [10]. According to the studies, 34\% of teachers experienced anxiety during a pandemic and $8 \%$ exhibited strong depressive emotions. It was also established that women show positive correlation with fear and depression and negative correlation with optimism $[10,11]$. The vast majority of education professionals are women [12].

Teachers who relied on information and communication technologies in their work during the COVID-19 pandemic noted that this form of work was a source of significant stress for them, which, as factored in the teacher success model based on the theory of self-determination, can cause emotional burnout [13].

The professional activity of a teacher involves close communication with students in an emotionally rich atmosphere. Emotional burnout is one of the possible fallouts thereof. Emotional burnout (EB) is a dynamic process that develops in stages, three of them. At the first stage, nervous tension rises from the atmosphere of chronic psychoemotional instability, destabilizing environment, increased responsibility, difficulties inherent to interactions with the given group of pupils/students. At the second stage, the person undergoing emotional burnout shows resistance, i.e., tries to develop protection against unpleasant impressions, with varying results. At the third stage, this person suffers depletion of mental resources, substandard emotional tone, both being the result of failure to resist at the second stage.

For teachers, DL means altered work and rest regimes, increased number of electronic devices in use, greater screen time associated with work (value several times as great as it was before DL), increased loads on the visual analyzer, musculoskeletal system. The way of life of teachers has changed, they were subjected to a significantly more intense neuro-emotional stress, and the loads on individual functional systems of the body have increased [14]. The peculiarities of organization of educational process in the DL mode, with forced self-isolation in the background, constitute an additional emotional burnout risk factor for teachers. This risk factor was only addressed in a small number of studies [15].

Thus, the problem of preserving health of teachers in the context of educational process intensification, growing reliance on information and communication technologies as part of the digital educational environment deployment, is of great scientific interest.

This study aimed to investigate the prevalence of risk factors affecting health and emotional state of teachers engaged in $\mathrm{DL}$, as well as subjective, teachers' assessment of the significance of these factors for health.

\section{METHODS}

We developed special online questionnaires to collect teachers' subjective assessments of their health, capability to follow a healthy lifestyle (HLS) when teaching traditionally (traditional learning, TL) and in the distance learning (DL) mode. The questionnaires were published as and distributed through Google Forms [16].

In 2019, we had 224 teachers fill in the online questionnaires during the TL period. In April 2020, during the DL period, we collected filled questionnaires from 619 teachers. The respondents lived in Moscow and the Moscow region, Yekaterinburg, Nizhny Novgorod, Voronezh, Ulyanovsk and other cities. Most of them were women. The average age of the respondents was 47.1 years. The questionnaires included questions aimed at collecting information about respondents' subjective assessment of their health; level of commitment to regular exercising (sports and other types of physical activity), eating at least three times a day, monitoring energy value of food; awareness about risk factors that can have a negative impact on health and emotional well-being.

Anthropometric measurements (body length and weight) were taken in 2019 during the TL period (45 teachers) and in 2021, when the DL period ended (72 teachers). Body mass index assessment followed the WHO standard, which considers values from 18.5 to 24.9 normal.

In February 2021, when the DL period has ended, we surveyed 72 teachers online, asking questions to collect data on their health status, anthropometric indicators, the influence of various factors on health and emotional well-being [17]. We also used V.V. Boyko questionnaire to identify EB in teachers and to establish groups of external and internal factors triggering it [18]. The group of organizational (external) factors included work conditions and socio-psychological activity (chronic psycho-emotional stress, unclear work organization and planning patterns, increased responsibility for the results of functional execution, unfavorable psychological atmosphere inherent to the professional activity). The group of internal factors included inclination to be emotionally rigid, intense internalization (perception and experience) of the circumstances of professional activity, weak motivation for emotional return in professional activity [18].

Factoring in the identified health risk factors peculiar to work and life of teachers, we built a regression model that describes their subjective assessment of their health in points (subjective positive assessment of health at $Y \leq 1$ ).

We calculated the odds ratio of developing overweight and obesity among teachers who adequately assessed and underestimated the health and emotional well-being risk factors.

Statistical data processing relied on Statistica 13.0 (StatSoft Inc.; USA), Student's $t$-test, $\chi^{2}$ test; the differences were considered significant at $p \leq 0.05$.

\section{RESULTS}

Only a third of teachers (30\%) of general primary and secondary education establishments considered themselves healthy.

During the TL period, every fifth teacher (21.4\%) underestimated the health risk associated with lack of regular exercise sessions (sports and other types of physical activity), every third (28.6\%) teacher underestimated the risk associated with having less than three meals a day, every second (55.8\%) teacher paid no attention to the energy value of food consumed.

DL had a specific effect on the way of life of teachers. The majority of respondents $(94.1 \%)$ reported decreased physical activity level; only half of them (56.2\%) mentioned maintaining physical activity level at the minimum. During the TL period, every second teacher (45.5\%) monitored his/her level of 
physical activity, while during the $\mathrm{DL}$ period it was only every third teacher $(33.0 \%)(p \leq 0,05)$.

Teachers examined when the DL period ended had their the average body mass index (BMI) at $26.9 \pm 0.7$, while during the TL period it was at $25.7 \pm 0.7$; every fourth $(23.8 \%)$ had some degree of obesity, every third (38.1\%) was overweight; about a third (38.9\%) of the respondents mentioned getting sick more often during the DL period, and only every seventh (15.3\%) teacher reported no sickness incidents at all.

After the DL period, only every eighth teacher (13.1\%) reported lack of EB symptoms. The remaining respondents mentioned presence of certain emerging or established EB symptoms.

At the "tension" stage, every second teacher (45.9\%) had a developed "experiencing traumatic circumstances" symptom, while every third (31.2\%) exhibited the "anxiety and depression" symptom.

At the "resistance" stage, half of the respondents signaled high values of the "inadequate selective emotional response" (54.1\%) and "professional deterioration" (50.8\%) symptoms; a third of them noted "emotional and moral disorientation" (32.8\%), "expanded emotional numbness field" (31.1\%).

At the "depletion" stage, every fourth teacher (22.9\%) had the "psychosomatic and psychovegetative disorders" symptom manifesting or dominating. After the $\mathrm{DL}$ period was over, teachers listed the risk factors that, in their opinion, had an impact on health and emotional state (Fig.).

According to the teachers surveyed, the risk factors affecting health and possible EB onset during the DL period were: work intensity, checked by every second respondent (61.1\%); low physical activity, checked by every third respondent (36.1\%); inappropriate nutrition (29.2\%); lack of timely medical care (29.2\%). Every fifteenth respondent mentioned "lack of knowledge on disease prevention" as a risk factor (6.9\%).

Teachers underestimating emotional well-being and health risk factors were 2.3 times more likely to grow obese $(\mathrm{OR}=0.40 ; 95 \% \mathrm{Cl}=0.22-0.70)$. We built a regression model that incorporates the most informative variables describing health status and EB development in teachers: age and gender characteristics, level of physical activity $(p \leq 0.05)$ :

$$
Y=1.48+0.23 X 1-0.80 X 2 \text {, }
$$

where $\mathrm{X} 1$ — age and gender characteristics; $\mathrm{X} 2$ — the level of physical activity.
The results highlight high hygienic value of physical activity as a controllable health risk factor.

\section{DISCUSSION}

The vast majority of general education teachers turned out to have no DL experience both in Russia and all over the world.

During the COVID-19 pandemic, school teachers did gain some experience against the background of need to adapt to the unprecedented DL process [18-20].

Analyzing the results of distance learning, pedagogical community realized the need to investigate physical and mental health status of all participants of the educational process occurring without in-person contact. Psychologists and teachers, physicians and physiologists state that in the absence of immediate live interaction of students and teachers it is more difficult for the former to perceive, understand and memorize the material presented, with the neuropsychic load suffered by the participants of such educational process increasing severalfold, which calls for adaptation of educational material, teaching methods and forms to fit the DL requirements [21-29].

The announced self-isolation regime, the switch to $D L$ and the associated need to master information and communication technologies within a limited period of time changed lifestyle of teachers, increased their work hours and the intensity of work, which can be regarded as an additional risk factor for the teachers' health and emotional sphere.

This testifies to the lack of teachers' awareness of healthy lifestyle practices, non-adherence thereto in daily and professional activities, which, with the growing deficit of physical activity and work intensity, contributed to physical health disorders, obesity and excess body weight and disturbed emotional well-being. The study has shown the importance of physical activity as a manageable risk factor in the context of health disorders and development of emotional burnout in teachers.

\section{CONCLUSIONS}

This study allowed establishing the fact that teachers underestimate the health and emotional well-being risk factors. The situation was obvious during the TL period and deteriorated further during the DL period. We have shown the high value of

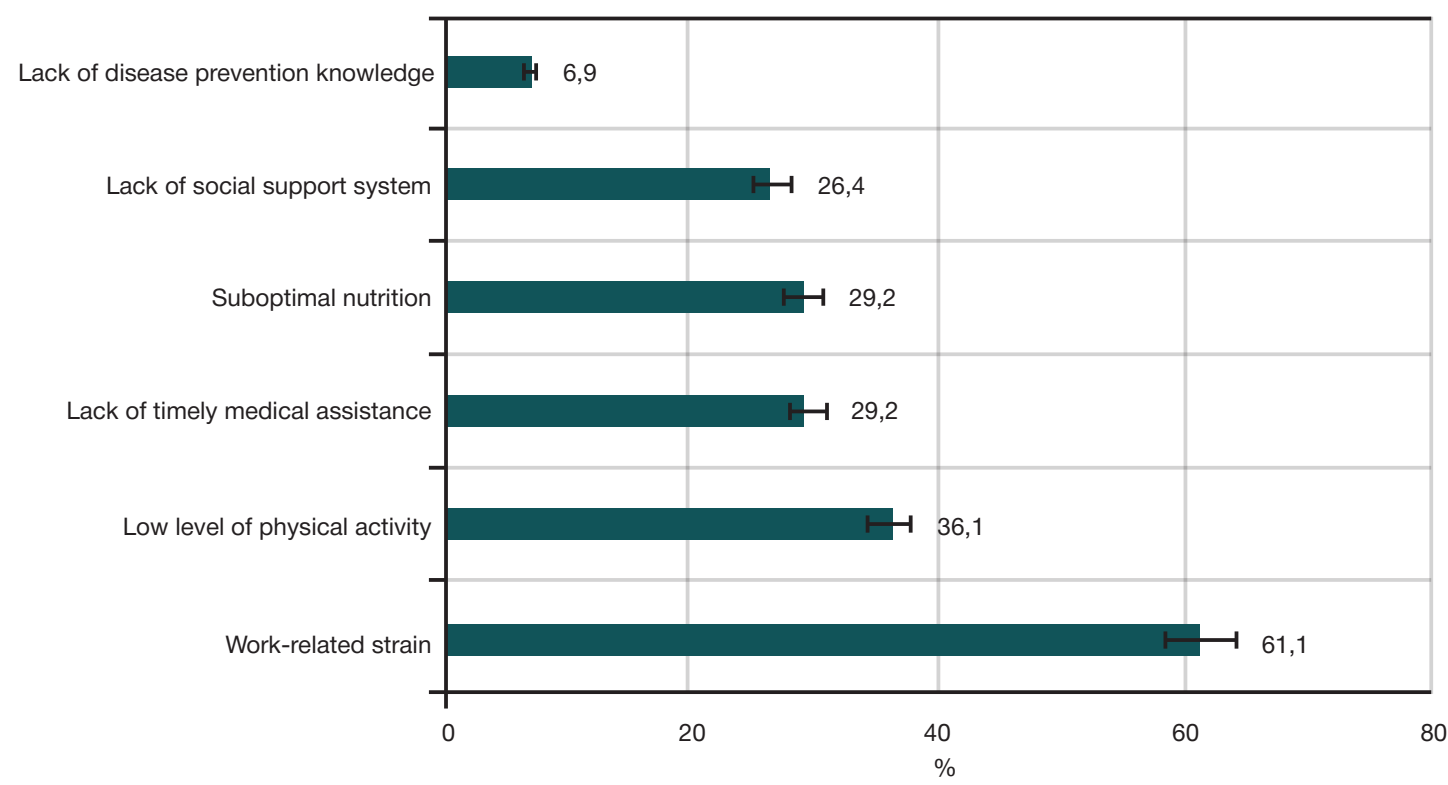

Fig. Risk factors that, according to the teachers, have affected their health and emotional state during the DL period 
an adequate subjective assessment of health and emotional well-being risk factors associated with physical activity, rational nutrition, the possibility of receiving timely medical care as components of a healthy lifestyle, as well as the high hygienic value of the level of awareness of healthy lifestyle practices health disorder prevention. The study underscores the high relevance of involving teachers in hygienic education and healthy lifestyles promotion activities. Such efforts will have a positive effect on their health and emotional well-being, including in the context of introduction of information and communication technologies into their professional lives, and will also increase the level of subjective assessment of the health risk factors.

The experience gained from long-term distance work exacerbated the existing problems resulting from the intensive introduction of information and communication technologies into the educational process, helped identify health and emotional well-being risk factors affecting all participants of the educational process, allows studying teachers' subjective assessment of existing risk factors, outlining priority areas for prevention efforts in the context of giving hygienic education to the teachers. Deployment of preventive programs for teachers, including those covering safe use of communication devices, work and rest balance, rational nutrition principles, optimal physical activity will not only help prevent deterioration of their health, preserve emotional well-being, but also increase their professional effectiveness and, consequently, the level of education received by their students.

\section{References}

1. GOST R 52653-2006 Informacionno-kommunikacionnye tehnologii v obrazovanii. Terminy i opredelenija. Dostupno po ssylke: https:// base.garant.ru/5922784/. Russian.

2. Lobachev SL, Soldatkin VI. Distancionnye obrazovatel'nye tehnologii: informacionnyj aspekt. M.: MJeSI, 2008. Russian.

3. Ferraro FV, Ambra Fl, Aruta L, et al. Distance learning in the covid-19 era: Perceptions in southern Italy. Educ Sci. 2020; 10 (12): 1-10.

4. Avksentev NA, Agranovich ML, Akindinova NV, i dr. Obshhestvo i pandemija: opyt i uroki bor'by s COVID-19 v Rossii. M., 2020; 744 s. Russian.

5. Kuchma VR, Sedova AS, Stepanova MI, Rapoport IK, Polenova MA, Sokolova SB, i dr. Osobennosti zhiznedejatel'nosti i samochuvstvija detej i podrostkov, distancionno obuchajushhihsja vo vremja jepidemii novoj koronavirusnoj infekcii (COVID-19). Voprosy shkol'noj i universitetskoj mediciny i zdorov'ja. 2020; (2): 4-23. Russian.

6. Popov VI, Milushkina OYu, Skoblina NA, Markelova SV, Sokolova NV, Dementev AA. Povedencheskie riski zdorov'ju studentov v period distancionnogo obuchenija. Gigiena i sanitarija. 2020; 99 (8): 854-60. Russian.

7. Milushkina OYu, Popov VI, Skoblina NA, Markelova SV Sokolova NV. Ispolzovanie jelektronnyh ustrojstv uchastnikami obrazovatel'nogo processa pri tradicionnoj i distancionnoj formah obuchenija. Vestnik Rossijskogo gosudarstvennogo medicinskogo universiteta. 2020; 3: 85-91. Russian.

8. Davis CR, Grooms J, Ortega A, et al. Distance learning and parental mental health during COVID-19. Educ Res. 2021; 50 (1): 61-64.

9. Sheregi FYe, Arefev AL, Carkov PE. Uslovija truda pedagogov: hronometricheskij i sociologicheskij analiz. M.: Centr sociologicheskih issledovanii, 2016. Russian.

10. Matiz A, Fabbro F, Paschetto A, et al. Positive impact of mindfulness meditation on mental health of female teachers during the COVID-19 outbreak in Italy. Int J Environ Res Public Health. 2020; 17 (18): 1-22.

11. Stachteas P, Stachteas C. The psychological impact of the COVID-19 pandemic on secondary school teachers. Psychiatriki. 2020; 31 (4): 293-301.

12. Lenskaja E, redaktor. Rossijskie pedagogi $v$ zerkale mezhdunarodnogo sravnitel'nogo issledovanija pedagogicheskogo korpusa (TALIS 2013). M.: Izd. dom Vysshej shkoly jekonomiki, 2015; 36 s. Russian.

13. Panisoara IO, Lazar I, Panisoara G, et al. Motivation and continuance intention towards online instruction among teachers during the COVID-19 pandemic: The mediating effect of burnout and technostress. Int J Environ Res Public Health. 2020; 17 (21): 1-29.

14. Milushkina OYu, Eremin AL, Popov VI, Skoblina NA, Markelova SV, Sokolova NV, i dr. Gigienicheskaja ocenka i optimizacija uslovij truda pedagogov $\vee$ period provedenija distancionnogo obuchenija. Medicina truda i promyshlennaja jekologija. 2020; 60 (7): 424-34. Russian.

15. Kirilova SA. Jemocional'noe vygoranie pedagoga $v$ uslovijah vynuzhdennogo perehoda $\mathrm{k}$ distancionnomu obucheniju: prichiny i profilaktika. Nauchnoe mnenie. 2020; 7-8: 76-82. Russian.

16. Pivovarov YuP, Skoblina NA, Milushkina OYu, i dr. Ispol'zovanie internet-oprosov $v$ ocenke osvedomlennosti ob osnovah zdorovogo obraza zhizni. Sovremennye problemy zdravoohranenija i medicinskoj statistiki. 2020; 2: 398-413. Russian.

17. Zhukov OF, Rossoshanskaya NS. Professional'noe zdorov'e uchitelja. Uchenye zapiski universiteta im. P.F. Lesgafta. 2011; 3 (73): 75-78. Russian.

18. Bojko W. Sindrom jemocional'nogo vygoranija v professional'nom obshhenii. SPb.: Sudarynja, 2012; 122 s. Russian.

19. Nikulicheva NV, Dyakova OI, Gluhovskaja OS. Organizacija distancionnogo obuchenija v shkole, kolledzhe, VUZe. Otkrytoe obrazovanie. 2020; 24 (5): 4-17. Russian.

20. Krjuchkova KS. Voprosy vkljuchenija onlajn-kursov v podgotovku budushhih uchitelej po osnovnym obrazovatel'nym programmam v VUZe. Vestnik pedagogicheskih nauk. 2020; 4: 78-84. Russian.

21. Leonidova GV, Valiahmetov RM, Bajmurzina GR, i dr. Problemy i perspektivy distancionnogo obuchenija $v$ ocenkah uchitelej i roditelej obuchajushhihsja. Jekonomicheskie i social'nye peremeny: fakty, tendencii, prognoz. 2020; 13 (4): 202-19. Russian.

22. Cheremoshkina LV, Koroleva YuM. Distancionnoe obuchenie: pljusy i minusy. Vestnik Gosudarstvennogo gumanitarnotehnologicheskogo universiteta. 2020; 3: 28-31. Russian.

23. Robert IV. Sovremennye informacionnye tehnologii v obrazovanii: didakticheskie problemy; perspektivy ispol'zovanija. M.: IIO RAO, 2010. Russian.

24. Tarenko LB. Osobennosti ispol'zovanija distancionnyh tehnologij pri podgotovke studentov informacionno-orientirovannyh special'nostej. Obrazovatel'nye tehnologii i obshhestvo. 2013; 16 (3): 552-60. Russian.

25. Chvanova MS, Hramova MV. Faktory perehoda distancionnyh tehnologij podgotovki specialistov na novyj uroven' razvitija. Vestnik Tambovskogo universiteta. Serija: Gumanitarnye nauki. 2010; 85 (5): 222-35. Russian.

26. Chvanova MS, Hramova MV. Modernizacija tehnologij distancionnogo obuchenija naukoemkih special'nostej. Tambov, 2012; 327 s.

27. Kaplan AM, Haenlein M. Higher education and the digital revolution: About MOOCs, SPOCs, social media, and the Cookie Monster. Business Horizons. 2016; 59 (4): 441-50.

28. Gorghiu LM, Gorghiu G, Dumitrescu C, Olteanu RL, Glava AE. Integrating ICT in traditional training-reactions of teachers and pupils' involved in FISTE project activities. Procedia-Social and Behavioral Sciences. 2011; 30: 1142-6.

29. Denisov El. Informational hygiene as a medical and biological tool for health preservation in the digital era. Am J Biomed Sci \& Res. 2019; 4 (2): 73-75. 


\section{Литература}

1. ГОСТ Р 52653-2006 Информационно-коммуникационные технологии в образовании. Термины и определения. Доступно по ссылке: https://base.garant.ru/5922784/.

2. Лобачев С. Л., Солдаткин В. И. Дистанционные образовательные технологии: информационный аспект. М.: МЭСИ, 2008.

3. Ferraro FV, Ambra Fl, Aruta $\mathrm{L}$, et al. Distance learning in the covid-19 era: Perceptions in southern Italy. Educ Sci. 2020; 10 (12): 1-10.

4. Авксентьев Н. А., Агранович М. Л., Акиндинова Н. В. и др. Общество и пандемия: опыт и уроки борьбы с COVID-19 в России. М., 2020; 744 с.

5. Кучма В. Р., Седова А. С., Степанова М. И., Рапопорт И. К., Поленова М. А., Соколова С. Б. и др. Особенности жизнедеятельности и самочувствия детей и подростков, дистанционно обучающихся во время эпидемии новой коронавирусной инфекции (COVID-19). Вопросы школьной и университетской медицины и здоровья. 2020; (2): 4-23.

6. Попов В. И., Милушкина О. Ю., Скоблина Н. А., Маркелова С. В., Соколова Н. В., Дементьев А. А. Поведенческие риски здоровью студентов в период дистанционного обучения. Гигиена и санитария. 2020; 99 (8): 854-60.

7. Милушкина О. Ю., Попов В. И., Скоблина Н. А., Маркелова С. В., Соколова Н. В. Использование электронных устройств участниками образовательного процесса при традиционной и дистанционной формах обучения. Вестник Российского государственного медицинского университета. 2020; 3: 85-91.

8. Davis CR, Grooms J, Ortega A, et al. Distance learning and parental mental health during COVID-19. Educ Res. 2021; 50 (1): 61-64.

9. Шереги Ф. Э., Аресьев А. Л., Царьков П. Е. Условия труда педагогов: хронометрический и социологический анализ. М.: Центр социологических исследований, 2016.

10. Matiz A, Fabbro F, Paschetto A, et al. Positive impact of mindfulness meditation on mental health of female teachers during the COVID-19 outbreak in Italy. Int J Environ Res Public Health. 2020; 17 (18): 1-22.

11. Stachteas P, Stachteas $C$. The psychological impact of the COVID-19 pandemic on secondary school teachers. Psychiatriki. 2020; 31 (4): 293-301.

12. Ленская Е., редактор. Российские педагоги в зеркале международного сравнительного исследования педагогического корпуса (TALIS 2013). М.: Изд. дом Высшей школы экономики 2015; 36 c.

13. Panisoara IO, Lazar I, Panisoara G, et al. Motivation and continuance intention towards online instruction among teachers during the COVID-19 pandemic: The mediating effect of burnout and technostress. Int J Environ Res Public Health. 2020; 17 (21): $1-29$.

14. Милушкина О. Ю., Еремин А. Л., Попов В. И., Скоблина Н. А. Маркелова С. В., Соколова Н. В. и др. Гигиеническая оценка и оптимизация условий труда педагогов в период проведения дистанционного обучения. Медицина труда и промышленная экология. 2020; 60 (7): 424-34.
15. Кирилова С. А. Эмоциональное выгорание педагога в условиях вынужденного перехода к дистанционному обучению: причины и профилактика. Научное мнение. 2020; 7-8: 76-82.

16. Пивоваров Ю. П., Скоблина Н. А., Милушкина О. Ю., и др. Использование интернет-опросов в оценке осведомленности об основах здорового образа жизни. Современные проблемы здравоохранения и медицинской статистики. 2020; 2: 398413.

17. Жуков О. Ф., Россошанская Н. С. Профессиональное здоровье учителя. Ученые записки университета им. П.Ф. Лесгафтта. 2011; 3 (73): 75-78.

18. Бойко В. В. Синдром эмоционального выгорания в просессииональном общении. СПб.: Сударыня, 2012; 122 с.

19. Никуличева Н. В., Дьякова О. И., Глуховская О. С. Организация дистанционного обучения в школе, колледже, ВУЗе. Открытое образование. 2020; 24 (5): 4-17.

20. Крючкова К. С. Вопросы включения онлайн-курсов в подготовку будущих учителей по основным образовательным программам в ВУЗе. Вестник педагогических наук. 2020; 4: 78-84.

21. Леонидова Г. В., Валиахметов Р. М., Баймурзина Г. Р. и др. Проблемы и перспективы дистанционного обучения в оценках учителей и родителей обучающихся. Экономические и социальные перемены: факты, тенденции, прогноз. 2020; 13 (4): 202-19.

22. Черемошкина Л. В., Королева Ю. М. Дистанционное обучение: плюсы и минусы. Вестник Государственного гуманитарнотехнологического университета. 2020; 3: 28-31.

23. Роберт И. В. Современные информационные технологии в образовании: дидактические проблемы; перспективы использования. М.: ИИО РАО, 2010.

24. Таренко Л. Б. Особенности использования дистанционных технологий при подготовке студентов информационноориентированных специальностей. Образовательные технологии и общество. 2013; 16 (3): 552-60.

25. Чванова М. С., Храмова М. В. Факторы перехода дистанционных технологий подготовки специалистов на новый уровень развития. Вестник Тамбовского университета. Серия: Гуманитарные науки. 2010; 85 (5): 222-35.

26. Чванова М. С., Храмова М. В. Модернизация технологий дистанционного обучения наукоемких специальностей. Тамбов, 2012; 327 с.

27. Kaplan AM, Haenlein M. Higher education and the digital revolution: About MOOCs, SPOCs, social media, and the Cookie Monster. Business Horizons. 2016; 59 (4): 441-50.

28. Gorghiu LM, Gorghiu G, Dumitrescu C, Olteanu RL, Glava AE. Integrating ICT in traditional training-reactions of teachers and pupils' involved in FISTE project activities. Procedia-Social and Behavioral Sciences. 2011; 30: 1142-6.

29. Denisov El. Informational hygiene as a medical and biological tool for health preservation in the digital era. Am J Biomed Sci \& Res. 2019; 4 (2): 73-75. 